\title{
Incomplete vertical root fracture associated with lateral compaction technique: a microscopic analysis
}

Fratura radicular vertical incompleta associada com a técnica de condensação lateral: Análise microscópica

Gisselle Moraima CHÁVEZ-ANDRADE ${ }^{1}$, Carolina ANDOLFATTO ${ }^{1}$, Loise Pedrosa SALLES ${ }^{1}$, Ana Lívia Gomes CORNÉLIO ${ }^{1}$, Gisele FARIA ${ }^{1}$, Idomeo BONETTI FILHO ${ }^{1}$

1 - Department of Restorative Dentistry - Araraquara Dental School - UNESP - Univ Estadual Paulista - Araraquara - São Paulo - Brazil.

\section{ABSTRACT}

Objective: This study evaluated the effects of root canal obturation employing lateral compaction technique and spreader load of $1.5 \mathrm{~kg}$ on the incidence of complete (CVRF) or incomplete vertical root fractures (IVRF). Material and Methods: Twenty-seven distal roots of extracted human mandibular molars were used. All root canals were prepared by biomechanical step-back technique and obturated by lateral compaction technique. The prepared roots were distributed into two groups: G1- experimental $(\mathrm{n}=17)$ and G2- control $(\mathrm{n}=10)$. During obturation, load of $1.5 \mathrm{~kg}$ was applied to a size \# 30 finger spreader. Pre- and post-obturation images of the coronal portion of the roots were captured by inverted digital microscopy and analyzed by one trained examiner. Data were evaluated by Fisher's test $(\mathrm{p}<0.05)$ using GrapH Pad Prism 5.0. Results: No roots exhibited CVRF. All fractures observed before and after obturation were IVRF or "other defects". In G2 (control group), there was no increase of IVRF number. Interestingly, G1 presented an increase in the IVRF number to $70.59 \%$ in the 12 teeth out of 17 teeth studied. The statistical analysis showed that the mean of IVRF increased significantly in G1 when compared to G2 ( $p<0.05$ ). Conclusion: The application of a $1.5 \mathrm{~kg}$ spreader load during lateral compaction technique does not produce complete vertical root fractures, but may produce incomplete fractures or "other defects".

\section{KEYWORDS}

Endodontics; Root canal obturation; Vertical root fracture.

\section{RESUIMO}

Objetivo: Este estudo avaliou os efeitos da obturação dos canais radiculares, empregando a técnica de condensação lateral com uma força do espaçador de $1,5 \mathrm{~kg}$, na incidência de fraturas radiculares verticais completas (FRVC) ou incompletas (FRVI). Material e Métodos: Foram usadas 27 raízes distais de dentes molares mandibulares humanos extraídos. Todas as raízes foram instrumentadas por meio da técnica clássica ápice-coroa e obturadas pela técnica de condensação lateral. Após o preparo biomecânico, as raízes foram distribuídas em 2 grupos: G1- experimental ( $\mathrm{n}=17$ ) e G2- controle $(\mathrm{n}=10)$. Durante a obturação, uma força de $1,5 \mathrm{~kg}$ foi aplicada ao espaçador digital \# 30. As imagens pré- e pós-obturação da superfície coronal das raízes foram capturadas por meio de um microscópio digital invertido e analisadas por um examinador treinado. Os dados obtidos foram avaliados por meio do teste de Fisher $(\mathrm{p}<0,05)$ usando o programa GrapH Pad Prism 5.0. Resultados: Não foram detectadas FRVC. Todas as fraturas observadas antes e após a obturação foram FRVI ou "outros defeitos". No G2 (grupo controle), não houve um aumento no número de FRVI. Curiosamente, G1 apresentou um aumento das FRVI em 70,59\% (12/17 raízes). A análise estatística mostrou que a média de FRVI aumentou significativamente no G1 quando comparado ao G2 ( $\mathrm{p}<0,05)$. Conclusão: A aplicação de uma força de $1,5 \mathrm{~kg}$ ao espaçador durante a realização da técnica de condensação lateral não produz fraturas radiculares verticais completas, mas pode produzir fraturas incompletas ou "outros defeitos".

\section{PALAVRAS-CHAVE}

Endodontia; Fratura radicular vertical; Obturação do canal radicular. 


\section{INTRODUCTION}

omplete or incomplete vertical root fracture is frequent occurrence in endodontically treated teeth (10.9 to $20 \%$ ) [1-6]. In the study of Seo et al. [7], out of 107 of fractured teeth, $33(30.8 \%)$ were treated endodontically and $14(13.1 \%)$ were diagnosed with vertical root fracture (VRF). Touré et al. [8] reported the factors to extraction of 119 teeth with a root canal treatment and the VRF was found in $13.4 \%$. These fractures are difficult to diagnose and treat $[4,6,9-11]$. In addition, they may start at the coronal portion of the tooth, at the root apex, or at any location within these structures $[12,13]$.

Prognosis of VRF is unfavorable, and they often result in bone loss and periodontal defects $[2,12,14,15]$. Presently, there is still a limited amount of treatment in extraction of root or resection of fractured tooth [3$5,12,16]$. VRF generally occurs as a result of trauma, root canal therapy, stress produced during post cementation [17], among other factors $[4,16,18-20]$.

The scientific literature suggests that the most common cause of root fractures is application of excessive loads during lateral compaction of the gutta-percha during canal filling $[2,10,19,21]$. Previous studies have demonstrated that the main determining factors for the occurrence of root fractures are: the design of the spreaders [22], combined with the stress generated during compaction $[18,23]$, canal width, canal taper, size and other characteristics of the tooth itself $[23,24]$. Moreover, pre-existing cracks, craze lines or incomplete fractures, especially those in direct contact with the root canal, may propagate and develop into fractures after the endodontic treatment [15].

Holcomb et al. [23] reported that the fracture load found to produce VRF was 1.5 $\mathrm{kg}$. Accordingly, this was the smallest observed fracture load which could serve as a guideline for limiting clinical spreader forces in an effort to avoid root fractures. However, new studies are necessary to confirm these data.

Therefore, the aim of this ex-vivo study was to evaluate by digital microscopy, the incidence of obturation of root canal employing lateral compaction technique and spreader load of $1.5 \mathrm{~kg}$ on the incidence of complete or incomplete vertical root fractures.

\section{MATERIAL AND METHODS}

\section{Matrix construction}

This study was submitted to and approved by the Ethical Committee of the Araraquara Dental School, UNESP (CEP 55/10). Twenty-seven extracted human mandibular permanent molars were selected and stored in 1\% thymol solution. The length of the selected teeth was between 18 and $21 \mathrm{~mm}$. These roots were observed at $8 \mathrm{x}$ magnification with a stereomicroscope (Leica Microsystems, Wetzlar, Germany) to exclude those with external cracks. Exclusion criteria were root canals allowing introduction of an instrument exceeding ISO size 15 at working length. After that, the working length was determined as $1 \mathrm{~mm}$ short of the length that a size $15 \mathrm{~K}$-file was observed to exit the apical foramen. The teeth had their crowns sectioned and the mesial roots were discarded through a cutting machine Isomet 1000 (Buehler, Lake Bluff, IL, USA). Proximal periapical radiographs of each distal root were taken to verify the presence of a single canal.

Specimens were placed in a small flask containing silicone-based impression material (Zetaplus, Zhermack, Italy) and embedded up to $1 \mathrm{~mm}$ from the coronal surface of the sectioned root in order to simulate the periodontal ligament, in accordance with Wilcox et al. [25] and Bhuva et al. [26], during instrumentation and obturation of the root canal.

\section{Biomechanical preparation}

The canal was instrumented to a size 40 K-file (Dentsply-Maillefer, Ballaigues, Switzerland) and step-back preparation 
was performed up to a size 55 K-file. Each canal was irrigated with $3 \mathrm{~mL}$ of $1 \%$ solution of sodium hypochlorite (Ciclo Farma Indústria Química Ltda., EPP Serrana, SP, Brazil) between each file change, using a syringe and a 27G endodontic needle (EndoEze irrigator, Ultradent, USA). After completion of instrumentation, the root canals were washed with $2 \mathrm{~mL}$ of $17 \%$ EDTA for 3 minutes and subsequently rinsed with $5 \mathrm{~mL}$ of distilled water and dried by using size 40 paper points (Tanari Indústria Ltda., São Paulo, SP, Brazil). The prepared roots were distributed into two groups: G1- experimental $(\mathrm{n}=17)$ and G2control $(\mathrm{n}=10)$.

\section{Root canal obturation}

In $\mathrm{G} 1$, the root canals were obturated by lateral compaction technique with standardized gutta-percha cone size 40 (Tanari Indústria Ltda., São Paulo, SP, Brazil) and AH Plus endodontic sealer (Dentsply De Trey, Germany) using a size C finger spreader (D1 diameter $0.3 \mathrm{~mm}, 0.04$ taper) (DentsplyMaillefer, Ballaigues, Switzerland). After that, four M-sized accessory gutta-percha cones (Tanari Indústria Ltda., São Paulo, SP, Brazil) were added in sequence, until the spreader could penetrate no more than $3 \mathrm{~mm}$. The spreader load applied $(1.5 \mathrm{~kg}$ ) was monitored by a Emic DL testing machine (Emic Equipamentos e Sistemas de Ensaio, São José dos Pinhais, PR, Brazil) throughout the compaction procedure, which was carried out by a single trained operator, in accordance with Soros et al. [14]. The accessory cone was compacted by inserting the spreader mounted in the machine at constant speed of $5 \mathrm{~mm}$ per min. Obturation was finalized by trimming the gutta-percha with a heated plugger. No vertical compaction was performed. In control group, root canal filling was performed in the similar way to the G1, but no forces were applied for placement of accessory cones.

\section{Digital microscopy analysis}

The coronal surfaces of the specimens were analyzed in digital microscopy images acquired after biomechanical preparation (pre-obturation) and after obturation (postobturation). The images were captured with an inverted digital microscope (Olympus MIC-D, Philippines) and analyzed by a single blinder trained examiner. Complete vertical root fracture (CVRF) was defined as a fracture which extend continuously from the root canal to the external root surface and incomplete vertical root fracture or "other defects" (IVRF) was defined as a fracture or craze line / cracks observed that did not extend from the root canal to the root surface, according with Onnink et al. [27] and Shemesh et al. [21]. The number of fractures found before and after obturation was computed and the data were evaluated by Fisher's test $(\mathrm{p}<0.05)$ using GrapH Pad Prism 5.0 (San Diego, CA, USA).

\section{RESULTS}

No roots exhibited a CVRF; all fractures observed before and after obturation were IVRF. In G2 (control group) there was no increase of IVRF number. In G1 there was an increase in the IVRF number to $70.59 \%$ (12 teeth) of the cases (Table 1). The comparison of variation of number of the IVRF between G1 and G2 showed that there was increase statistically significant in G1 (p < 0.05) (Table 1).

Table 1 - Comparison of IVRF increased number after obturation

\begin{tabular}{cccc}
\hline Groups & Total $(\mathbf{n})$ & Roots with no IVRF increased number & Roots with IVRF increased number \\
\hline G1-Experimental & 17 & $5(29.41 \%)$ & $\mathbf{1 2 ( 7 0 . 5 9 \% ) ^ { \mathrm { a } }}$ \\
\hline G2-Control & 10 & $10(100 \%)$ & $\mathbf{0}^{\mathrm{b}}$ \\
\hline
\end{tabular}

G, group; n, number of roots; IVRF, incomplete vertical root fracture. Different letters indicate statistically significant difference $(p<0.05)$. 


\section{DISCUSSION}

This study demonstrated that spreader load of $1.5 \mathrm{~kg}$ during lateral compaction technique induces an increase of number of IVRF, compared with the group that was not employed load with the finger spreader. This result is in accordance with previous studies which have suggested lateral compaction technique as a possible causal factor for VRF [12-14,25,28,29].

Wilcox et al. [25] demonstrated that a load of $3.3 \mathrm{~kg}$ applied during lateral compaction technique caused VRF in $35.29 \%$ of cases. Soros et al. [14] found that spreader load required for IVRF varied from 4.3 to $26.9 \mathrm{~kg}$. In another study, Shemesh et al. [21] evaluated ex vivo the incidence of fractures and defects in root dentine after root canal preparation and filling by lateral compaction technique, using a spreader load of $2 \mathrm{~kg}$. The lateral compaction group had significantly more fractures and defects than all other groups (no preparation, only preparation and no compaction).

Recently, Barreto et al. [15] evaluated ex vivo the effects of root canal preparation and filling techniques on the incidence of dentinal defects and VRFs. In the lateral compaction group, the teeth were filled by using a size $C$ spreader and FM gutta-percha cones controlling the load to a maximum of $2 \mathrm{~kg}$. They found CVRF $(13.3 \%)$ and other defects $(46.6 \%)$ in the roots of lateral compaction group in comparison with prepared group (not obturation) that shown other defects in 53.3\% and no CVRF.

Previous studies have shown that the mean maximum spreader load applied during lateral compaction ranges from 1 to $3 \mathrm{~kg}[12,30]$. We applied a standardized load of $1.5 \mathrm{~kg}$ to the spreaders during root canals obturation, which was in accordance with the study of Holcomb et al. [23] where they suggested that $1.5 \mathrm{~kg}$ load to be regarded as a limit in clinical practice. Interestingly, in our study this load led to an increase in the IVRF number.

In the present study we used size $C$ finger spreaders during lateral compaction because they are compatible with the prepared root canal width. Thinner finger spreaders usually lead to spaces and sealer removal in the apical region without the accessory cone filling that gap in its entirety, leaving voids in the apical third [31].

VRF can be caused by a variety of factors and generally lead to a significant number of endodontic failures. Treatment of VRF is difficult and their prognosis is reserved. These findings are of great importance for the daily clinical practice: endodontists should be aware that application of excessive load during lateral compaction may potentially produce IVRF.

Within the limitations of this study, it was concluded that a load of $1.5 \mathrm{~kg}$ during obturation of root canal by lateral compaction technique does not induce the formation of complete vertical root fractures, but might be considered as a potential risk to produce incomplete vertical root fractures or "other defects".

\section{REFERENCES}

1. Floratos SG, Kratchman SI. Surgical management of vertical root fractures for posterior teeth: report of four cases. J Endod. 2012;38(4):550-5.

2. Bhaskar U, Logani A, Shah N. True vertical tooth root fracture: Case report and review. Contemp Clin Dent. 2011;2(3):265-8.

3. Topcuoglu HS, Arslan H, Keles A, Koseoglu M. Fracture resistance of roots filled with three different obturation techniques. Med Oral Patol Oral Cir Bucal. 2012;17(3):e528-32.

4. Zare Jahromi M, Mirzakouchaki P, Mousavi E, Navabi AA. Fracture strength of mesiobuccal roots following canal preparation with hand and rotary instrumentation: an in vitro study. Iran Endod J. 2011;6(3):125-8.

5. Rosen E, Tsesis I, Tamse A, Bjorndal L, Taschieri S, Givol N. Medicolegal aspects of vertical root fractures in root filled teeth. Int Endod J. 2012;45(1):7-11.

6. Edlund M, Nair MK, Nair UP. Detection of vertical root fractures by using cone-beam computed tomography: a clinical study. J Endod. 2011;37(6):768-72.

7. Seo DG, Yi YA, Shin SJ, Park JW. Analysis of factors associated with cracked teeth. J Endod. 2012;38(3):288-92. 
8. Toure B, Faye B, Kane AW, Lo CM, Niang B, Boucher Y. Analysis of reasons for extraction of endodontically treated teeth: a prospective study. J Endod. 2011;37(11):1512-5.

9. Obermayr G, Walton RE, Leary JM, Krell KV. Vertical root fracture and relative deformation during obturation and post cementation. J Prosthet Dent. 1991;66(2):181-7.

10. Ozer SY, Unlu G, Deger Y. Diagnosis and treatment of endodontically treated teeth with vertical root fracture: three case reports with two-year follow-up. J Endod. 2011;37(1):97-102.

11. Tsesis I, Rosen E, Tamse A, Taschieri S, Kfir A. Diagnosis of vertical root fractures in endodontically treated teeth based on clinical and radiographic indices: a systematic review. J Endod. 2010;36(9):1455-8.

12. Lertchirakarn V, Palamara JE, Messer HH. Load and strain during lateral condensation and vertical root fracture. J Endod. 1999;25(2):99-104.

13. Pitts DL, Natkin E. Diagnosis and treatment of vertical root fractures. J Endod. 1983;9(8):338-46.

14. Soros C, Zinelis S, Lambrianidis T, Palaghias G. Spreader load required for vertical root fracture during lateral compaction ex vivo: evaluation of periodontal simulation and fracture load information. Oral Surg Oral Med Oral Pathol Oral Radiol Endod. 2008;106(2):e6470.

15. Barreto MS, Moraes Rdo A, da Rosa RA, Moreira CH, So MV, Bier CA. Vertical root fractures and dentin defects: effects of root canal preparation, filling, and mechanical cycling. J Endod. 2012;38(8):1135-9.

16. Ersev H, Yilmaz B, Pehlivanoglu E, Ozcan-Caliskan E, Erisen FR. Resistance to vertical root fracture of endodontically treated teeth with MetaSEAL. J Endod. 2012;38(5):653-6.

17. Boyarsky H, Davis R. Root fracture with dentin-retained posts. Am J Dent. 1992;5(1):11-4.

18. Pitts DL, Matheny HE, Nicholls Jl. An in vitro study of spreader loads required to cause vertical root fracture during lateral condensation. J Endod. 1983;9(12):544-50.

19. Mireku AS, Romberg E, Fouad AF, Arola D. Vertical fracture of root filled teeth restored with posts: the effects of patient age and dentine thickness. Int Endod J. 2010;43(3):218-25.
20. Gerek M, Baser ED, Kayahan MB, Sunay H, Kaptan RF, Bayirli G. Comparison of the force required to fracture roots vertically after ultrasonic and Masserann removal of broken instruments. Int Endod J. 2012;45(5):429-34.

21. Shemesh H, Bier CA, Wu MK, Tanomaru-Filho M, Wesselink PR. The effects of canal preparation and filling on the incidence of dentinal defects. Int Endod J. 2009;42(3):208-13.

22. Dang DA, Walton RE. Vertical root fracture and root distortion: effect of spreader design. J Endod. 1989;15(7):294-301.

23. Holcomb JQ, Pitts DL, Nicholls JI. Further investigation of spreader loads required to cause vertical root fracture during lateral condensation. J Endod. 1987;13(6):277-84.

24. Deutsch AS, Musikant BL, Cavallari J, Silverstein L, Lepley J, Ohlen $\mathrm{K}$, et al. Root fracture during insertion of prefabricated posts related to root size. J Prosthet Dent. 1985;53(6):786-9.

25. Wilcox LR, Roskelley C, Sutton T. The relationship of root canal enlargement to finger-spreader induced vertical root fracture. $J$ Endod. 1997;23(8):533-4.

26. Bhuva B, Patel S, Wilson R, Niazi S, Beighton D, Mannocci F. The effectiveness of passive ultrasonic irrigation on intraradicular Enterococcus faecalis biofilms in extracted single-rooted human teeth. Int Endod J. 2010;43(3):241-50.

27. Onnink PA, Davis RD, Wayman BE. An in vitro comparison of incomplete root fractures associated with three obturation techniques. J Endod. 1994;20(1):32-7.

28. Meister F, Jr., Lommel TJ, Gerstein H. Diagnosis and possible causes of vertical root fractures. Oral Surg Oral Med Oral Pathol. 1980;49(3):243-53.

29. Harvey TE, White JT, Leeb IJ. Lateral condensation stress in root canals. J Endod. 1981;7(4):151-5.

30. Ricks-Williamson LJ, Fotos PG, Goel VK, Spivey JD, Rivera EM, Khera SC. A three-dimensional finite-element stress analysis of an endodontically prepared maxillary central incisor. J Endod. 1995;21(7):362-7.

31. Souza EM, Wu MK, van der Sluis LW, Leonardo RT, Bonetti-Filho I, Wesselink PR. Effect of filling technique and root canal area on the percentage of gutta-percha in laterally compacted root fillings. Int Endod J. 2009;42(8):719-26.

\section{Gisselle Moraima Chávez-Andrade} (Corresponding author)

Rua Humaitá 1680 - Centro, Araraquara Received: 2013 Jun 05 14801-903 - São Paulo - SP - Brazil. Accepted: 2013 Jun 24 